\title{
Socjologiczne rozumienie wartości w aspekcie relacjonistycznym
}

U względnianie społecznego kontekstu wartości stanowi specyfikę socjologicznego ujmowania kategorii aksjologicznych. $Z$ tej racji do oglądów wartości, ale i interesów niezwykle pomocna jest perspektywa relacjonistyczna ${ }^{1}$. Fenomen relacyjności rozumiany jest jako - mniej czy bardziej świadome - odniesienia podmiotów do określonych obiektów. Relacje społeczne (ich determinanty, taksonomie, funkcje i konsekwencje) stanowią w socjologii istotny przedmiot analiz i badań. Wyeksponowanie roli interakcji społecznych zostało przez niektórych określone mianem „trzeciej socjologii”" Natomiast formowanie się tzw. paradygmatu relacyjnego (relacyjności) we współczesnej teorii społecznej zostało uznane za przyczynę krystalizowania się pewnej perspektywy analityczno-eksploracyjnej czy też wyłaniania się nowej subdyscypliny, która różnie jest określana, np. jako socjologia relacyjna czy socjologia relacji (relacyjności) ${ }^{3}$.

* Dr hab. JAN Szymczyк, prof. KUL - Katedra Socjologii Makrostruktur i Ruchów Społecznych, Instytut Socjologii, Wydział Nauk Społecznych Katolickiego Uniwersytetu Lubelskiego Jana Pawła II, e-mail: j.szymczyk5@gmail.com, ORCID: 0000-0002-2595-6936.

${ }^{1} \mathrm{~W}$ niniejszym tekście przyjmujemy stosowanie terminu „relacjonistyczna”, ale także zamiennie takich określeń, jak: „psychospołeczna perspektywa”, „podejście podmiotowo-przedmiotowe”. Niektórzy autorzy używają terminu „relacjonalny” (np. „relacjonalny charakter wartości”). (M. Ziółkowski, Przemiany interesów i wartości społeczeństwa polskiego. Teorie, tendencje, interpretacje, Wydawnictwo Fundacji Humaniora, Poznań 2000, s. 55).

2 P. Sztompka, Kapitat społeczny. Teoria przestrzeni międzyludzkiej, Wydawnictwo Znak Kraków 2016, s. 25. Autor ten na określenie tej „trzeciej socjologii” proponuje metaforę „przestrzeni międzyludzkiej” (tamże, s. 28). Jednocześnie przypomina, że „socjologia pierwsza” odwoływała się do metafory organizmu i nakazywała badać całości i systemy społeczne (August Comte, Herbert Spencer, Talcott Parsons), z kolei „druga socjologia” (Max Weber) nawiązywała do idei atomu i chciała skupić się na analizie działań jednostki będącej fundamentalnym składnikiem społeczeństwa (tamże, s. 21-24).

${ }^{3}$ P. Donati, Sociologia della relazione, Società editrice il Mulino, Bologna 2013; P. Donati, M.S. Archer, The Relational Subject, Cambridge University Press, Cambridge 2015. 
„Wykorzystuje” ona zasoby socjologii (teorie, metody, narzędzia badawcze itp.) do analizy czy badania zjawiska relacyjności ${ }^{4}$. Jednak niektórzy autorzy, którzy nią się zajmują, zbyt mocno koncentrują się na samym fenomenie relacyjności, kryteriach jej różnorodności, typologii, a „biorą w nawias” kwestię etiologicznego sprawstwa interakcji. Dlatego adekwatne ujmowanie „anatomii” relacyjności powinno być poprzedzone eksplikacjami z zakresu ontologii, czyli chodzi o wyjaśnienie specyfiki bytowej danych aktorów jako uczestników (sprawców) interakcji. A następnie dopiero naturalną konsekwencją takiej refleksji powinien być opis tego, co dzieje się między podmiotami i co tworzy w ten sposób sieci interakcji. Istotę socjologicznego paradygmatu relacyjności, także w odniesieniu do świata wartości, powinny zatem stanowić trzy dymensje: analiza elementów podmiotowości aktorów (np. sprawstwa, świadomości, refleksyjności) oraz ich możliwości i zasobów; ukazanie determinantów ich zachowań i działań czy potencjalności (różnej proweniencji); wreszcie uwzględnienie jednostkowych czy grupowych aktualizacji czy kreacji jako wypadkowych dwóch pierwszych aspektów.

Celem niniejszego tekstu jest zaprezentowanie, $\mathrm{z}$ podmiotowo-przedmiotowej (psychospołecznej) perspektywy, elementów ontologii wartości, a następnie ukazanie przykładów aplikacji stanowiska relacjonistycznego. W przypadku ostatniej kwestii przedmiotem analizy uczyniono korelacje zachodzące między wartościami i interesami, oraz kategoriami aksjologicznymi i więziami sąsiedzkimi Polaków, korzystając w tym względzie z wyników eksploracji socjologicznych, głównie Centrum Badania Opinii Społecznej (CBOS).

\section{Ontologiczny status wartości w socjologii}

Od ponad trzech dekad społeczeństwo polskie doświadcza procesu transformacji różnych dziedzin życia publicznego. Przemiany te dotyczą także sfery aksjologicznej i świadomościowej. Wartości pojmowane jako cele działań funkcjonują w świadomości jednostek i są traktowane jako przekonania potencjalne, uruchamiane i aktualizowane w adekwatnych sytuacjach i kontekstach, kiedy pojawiają się odpowiednie racje, motywacje czy wyzwania. Zwłaszcza wartości naczelne (preferowane lub też uznawane za cele życiowe) odgrywają szczególną rolę w systemie przekonań każdej osoby. Wprawdzie pierwszorzędnymi podmiotami, „nosicielami” wartości są jednostki to jednak kategorie aksjologiczne w socjologii ujmowane są w społecznym kontekście. Traktuje się je jako w pewnym zakresie społecznie usankcjonowane i charakterystyczne dla danej społeczności, kultury.

${ }^{4}$ Analogicznie jak niektórzy wykorzystują socjologię do refleksji nad tożsamością (T. Paleczny, Socjologia tożsamości, Oficyna Wydawnicza AFM Kraków 2008). 
Można zatem przyjąć - z socjologicznej perspektywy - że termin „wartość” oznacza dowolny przedmiot materialny lub idealny, ideę lub instytucję, obiekt wyimaginowany lub realny, w stosunku do którego podmioty przyjmują postawę szacunku, przypisują im ważną rolę w swoim życiu i dążenia do jego osiągnięcia odczuwają jako przymus. ${ }^{5}$ W sumie wartość może być rozumiana jako: zjawisko autonomiczne, niezależnie od ludzkich opinii i sądów; kierunek motywacji w relacji do działań człowieka; przedmiot, ale i kryterium pozytywnej oceny oraz wyboru danych przedmiotów, idei, cech, co łączy się z afirmacją określonych bytów czy stanów rzeczy pożądanych przez daną jednostkę, dzięki czemu stają się obiektami postaw ${ }^{6}$.

Rudymentarną kwestią, jeśli chodzi o ujmowanie wartości z perspektywy relacjonistycznej, jest problem ontologicznego statusu wartości, a więc czym one są, jaki jest ich charakter i sposób istnienia. Wartości mają dla jednych jednostek charakter obiektywny (istnieją w przedmiotach), dla innych subiektywny (bytują w umyśle oceniajaccego podmiotu ${ }^{7}$. Wartościa - w sensie przedmiotowym - jest pewien zewnętrzny obiekt, ku któremu inklinują się, z takiej czy innej przyczyny, podmioty (tzn. ich zachowania, postawy, potrzeby, pożądania itp.). Przy czym wartością może być ów przedmiot w całości bądź tylko pewne jego cechy, czyli te, do których odnosi się aktywność podmiotu. Czasem też wartością nazywa się nie przedmiot (cały albo jego część), ale znaczenie czy istotność, jakie ów obiekt (bądź jego fragment) ma dla podmiotu (np. sens chleba jako chleba dla głodnego). Mówi się więc, że coś jest wartością dla kogoś albo, że coś ma wartość dla kogoś ${ }^{8}$. Obiekty-wartości występują w mniej lub bardziej systematycznych powiązaniach z innymi obiektami-wartościami. I w kontekście tego rodzaju współzależności systemów wartości przebiega życie i funkcjonowanie podmiotów. Te układy kategorii aksjologicznych mają - zdaniem Floriana Znanieckiego - swój autonomiczny ład wewnętrzny (niezależny od jakiegokolwiek podmiotowego ujęcia czy zewnętrznych oddziaływań społecznych), czyli jest on fenomenem zobiektywizowanym. Ową obiektywność czy wewnętrznie niezależny ład układów wartości, Znaniecki przypisuje m.in. takim systemom kulturowym wykreowanym przez człowieka, jak: mity, systemy prawne, język czy teorie naukowe9.

Z kolei ujmowanie kategorii aksjologicznych od strony podmiotowej specyfikuje się tym, że wartości są „osadzone” w stanach świadomości, przeżyciach,

${ }^{5}$ J. Szczepański, Elementarne pojęcia socjologii, PWN, Warszawa 1970, s. 97.

${ }^{6}$ H. Świda, Młodzież a wartości, WSiP, Warszawa 1979, s. 18-35.

7 S. Kowalczyk, Człowiek w poszukiwaniu wartości. Elementy aksjologii personalistycznej, Wydawnictwo KUL, Lublin 2006, s. 133 nn.

${ }^{8}$ M. Ziółkowski, Wartości, w: Encyklopedia socjologii, t. 4, Oficyna Naukowa, Warszawa 2002, s. 290 .

9 F. Znaniecki, Nauki o kulturze. Narodziny i rozwój, PWN, Warszawa 1992, s. 284. 
osobowości człowieka. Oczywiście, wiele z nich posiada swój zewnętrzny wyraz w postaci możliwości wpływania na zachowania, postawy czy potrzeby jednostek. Z wartościami łączą się pewne fakty psychiczne o charakterze emotywno-poznawczym (chodzi o rolę uczuć, rozumu w ich internalizacji). Ale kategorie aksjologiczne stanowią przede wszystkim specyficzny typ przekonań (odnoszący się m.in. do tego, jak się powinno lub nie powinno postępować oraz co należy uczynić celem swoich dążeń, a jakie pożądania są jałowe). Wszelkie wartości - zgodnie z zasadą „współczynnika humanistycznego" - są dla kogoś (określonych podmiotów). Innymi słowy, przedmioty są obdarzane mianem „wartości” przez podmiotowe doświadczenie, gdyż to ostatecznie człowiek dokonuje ich oceny, rangowania. Oczywiście, możliwe są różne stopnie uświadamiania czy internalizacji wartości oraz rozmaite typy doświadczenia aksjologicznego (np. bezrefleksyjne zaspokajanie rudymentarnych potrzeb, działania nawykowe, pasywne podporządkowanie się, niezbyt klarownie wyartykułowane odczucia, zracjonalizowane preferencje i przemyślane cele życiowe).

Można zatem przyjąć, że wartości mają podmiotowo-indywidualny charakter, gdyż jednostka je odczuwa, uznaje, dokonuje ich taksonomii. Jednak relatywnie pełny obraz wartości daje nam dopiero ich podmiotowo-przedmiotowe czy psychospołeczne ujęcie. Oznacza to, że kategorie aksjologiczne mają również społeczny profil, gdyż jednostki za układy odniesienia, jeśli chodzi np. o ich wybór, aplikację przyjmują różnego typu społeczno-kulturowe czy religijne konteksty i uwarunkowania. Syntezę tych różnych ujęć wartości stanowi relacjonistyczna perspektywa, która jest najbardziej właściwym podejściem do analizy kategorii aksjologicznych. Stanowisko relacjonistyczne można uznać za próbę poszukiwania kompromisu między zwolennikami subiektywnego i obiektywnego statusu wartości. Wartość jest bowiem wynikiem relacji doznającego i aktywnego podmiotu wobec pewnych przedmiotów (obiektów). Kategorie aksjologiczne mają więc podwójny fundament bytowy: są osadzone w podmiotowej rzeczywistości człowieka (np. w jego świadomości) oraz w pozapodmiotowo istniejących stanach rzeczy. Przy czym te ostatnie są obdarzane mianem „wartości” przez ludzkie doświadczenie ${ }^{10}$.

Z relacjonistyczną czy psychospołeczną perspektywą ujmowania kategorii aksjologicznych koresponduje tzw. aktywistyczna koncepcja wartości. Fundamentem dla niej jest pojęcie „wartości społecznej” w ujęciu Williama I. Thomasa i Floriana Znanieckiego ${ }^{11}$. Otóż wartość społeczna to „wszelki przedmiot posiadający empiryczną treść, dostępną członkom grupy społecz-

\footnotetext{
10 M. Gołaszewska, Internalizacja wartości, „Etyka” 1978, t. 16, s. 89.

11 Wątek wartości w tym wspólnym dziele jest bez wątpienia wkładem samego Znanieckiego.
} 
nej, oraz znaczenie, wskutek którego jest on lub może być obiektem działalności" ${ }^{12}$. Z tej definicji wynika, że określony fenomen staje się wartością o tyle, o ile podmioty nakierowują na niego swoje działania. W ten sposób „aktywistyczna” wartość różni się od deklarowanej wartości czy postawy, która zawiera dyspozycję do działania i nie traktuje występowania w niej aktywności jako warunku koniecznego zaistnienia kategorii aksjologicznej.

Dla socjologicznej refleksji nad wartościami, uwzględniającej relacjonistyczne podejście, istotne jest pojęcie systemu (hierarchii) kategorii aksjologicznych, który implikuje strukturę czy organizację wartości w życiu i świadomości jednostki. Z perspektywy systemu wartości analizuje się również określone postawy (stanowiska) podmiotów, dokonywane przez nich wybory w zakresie celów, środków i motywacji w odniesieniu do ich działań, zachowań, aktywności w życiu społecznym. Przy czym cechą wartości jest znacznie większa stabilność w systemie przekonań jednostki, gdzie zajmują miejsce centralne i wywierają organizujący wpływ na inne, bardziej fluktuacyjne składniki owego układu (np. postawy czy dyspozycje do zachowań). System wartości jest układem kategorii poznawczych (służących człowiekowi do opisu i oceny świata), w którym pewne fakty, zjawiska, obiekty uważa on za szczególnie ważne dla siebie i innych. Ponadto układ ten odgrywa istotną rolę w strukturze osobowości jednostki, gdyż wyzwala określone emocje osoby wobec otaczających ludzi i zjawisk; ma wpływ na kierunek i sposób zachowania w różnych sytuacjach życiowych. Stanowi jawny lub ukryty mechanizm działania człowieka. Nadaje indywidualne piętno jego aktywnościom ${ }^{13}$. Jest także pewnym schematem pojęciowym, konstruktem teoretycznym, który odzwierciedla organizację hierarchiczną (rangowe uporządkowanie) wszystkich wartości jednostki, choć uwzględnia również horyzontalny aspekt powiązań kategorii aksjologicznych między sobą nawzajem ${ }^{14}$. A zatem system wartości to pewien ich zbiór oraz określony typ powiązań czy relacji między nimi (wszelkie związki i współzależności).

Można wskazać m.in. trzy modelowe postacie powiązań (relacji) między typami wartości: po pierwsze, chodzi o powiązania wyłącznie pionowe (jest to wertykalny układ, w którym wartości znajdujące się wyżej w hierarchii, dominują nad pozostałymi). Po drugie, są to powiązania wyłącznie poziome (spójność tego układu gwarantują horyzontalne relacje współrzędności istniejące między kategoriami aksjologicznymi). Po trzecie, w grę wchodzą powiązania pionowe i poziome (na różnych poziomach tej hierarchii zlokalizowanych jest więcej niż jeden typ wartości, stąd istnieją między nimi

12 W. I. Thomas, F. Znaniecki, Chłop polski w Europie i Ameryce, t. 1, LSW, Warszawa 1976, s. 54.

13 A. Gurycka, Systemy wartości młodzieży licealnej 1978-1989, „Psychologia Wychowawcza” 1991, nr 2, s. 132.

${ }^{14}$ J. Koralewicz-Zębik, System wartości a struktura społeczna, Ossolineum, Wrocław, 1974, s. 47. 
relacje równorzędności, ale także podporządkowania, czyli jedne z nich są bardziej cenione, a inne mniej istotne dla jednostki ${ }^{15}$.

Dla zilustrowania systemowego, a więc i do pewnego stopnia relacjonistycznego sposobu ujmowania wartości, przywołajmy eksploracje Centrum Badań Opinii Społecznej. Wynika z nich, że niewątpliwie „orientację na rodzinę", jaka wciąż jest obecna w świadomości badanych Polaków i do tego znajduje się na czele preferowanych kategorii aksjologicznych - można uznać za „oś systemu wartości” naszych rodaków. Autentyczne więzi rodzinne są dla wielu Polaków rodzajem obrony przed różnymi formami zmarginalizowania, wykluczenia, osamotnienia itp. oraz w ciągu ostatnich sześciu lat skala bliskich kontaktów w ramach rodziny nie zmieniła się znacząco ${ }^{16}$. Więzi rodzinne w Polsce cechują się dużą siłą i stabilnością. Wpływa na to częstotliwość spotkań z bliskimi (utrzymująca się na wysokim poziomie) oraz skala zażyłych, przyjacielskich relacji między krewnymi. Również poziom satysfakcji z życia rodzinnego jest u Polaków nadal wysoki. Osoby, na wsparcie których zawsze można liczyć, to niezmiennie przede wszystkim członkowie najbliższej rodziny, a więc współmałżonkowie, rodzice, rodzeństwo oraz dzieci, a w odniesieniu do jednostek niebędących w związkach sformalizowanych - partnerzy lub partnerki ${ }^{17}$. Nic też dziwnego, że ponad połowa eksplorowanych (54\%) za najważniejszą wartość uznaje rodzinę, która stanowi dla nich podstawowe środowisko działania i samorealizacji, nadaje sens ich życiu ${ }^{18}$. Inną orientacją życiową, która jest istotna w systemie wartości Polaków to walor zdrowia (38\% wskazań), jego utrzymanie i brak chorób ${ }^{19}$.

Jaki zatem sens posiada perspektywa relacjonistyczna w sferze aksjologii? Otóż umożliwia ona relatywnie zintegrowany ogląd zróżnicowanych postaw (stanowisk), jakie podmioty zajmują wobec wartości. Dla przykładu wartości mogą być ujmowane, po pierwsze, jako istniejące w przedmiotach materialnych i niematerialnych (rozumienie przedmiotowe). Po drugie, utożsamia się je z działaniami, czyli związane są z samą relacją, jaka dokonuje się pomiędzy

${ }^{15}$ S. Jałowiecki, Struktura systemu wartości. Studium zróżnicowań międzygeneracyjnych, PWN, Warszawa-Wrocław 1978, s. 38-39.

16 Więzi rodzinne. Komunikat z badań, CBOS, nr 61/2019, Warszawa, kwiecień 2019, s. 6.

17 Tamże, s. 7.

18 Sens życia - wczoraj i dziś. Komunikat z badań, CBOS, nr 41/2017, Warszawa, kwiecień 2017, s. 3.

19 Tamże, s. 3. Ponadto tylko dla 5\% naszych rodaków najbardziej liczą się wartości religijne: wiara w Boga (4\%), perspektywa zbawienia (1\%). Istotnie mniej Polaków niż kiedyś odwołuje się do sfery wartości moralnych (3\%) i praktyki z tym związanej, np. bycia dobrym człowiekiem (1\%), pomagania innym, postępowania uczciwie (2\%). Natomiast więcej jest takich badanych, dla których istotne znaczenie mają kwestie życia społecznego (spokój, bezpieczeństwo, sprawiedliwość i relacje z ludźmi - 8\% wskazań) (tamże, s. 5). 
podmiotem a przedmiotem (rozumienie „pośrednie”). Po trzecie, kategorie aksjologiczne sytuuje się w doświadczeniu człowieka (rozumienie podmiotowe) ${ }^{20}$.

Aplikacja relacjonistycznej perspektywy umożliwia również analizę pojęcia internalizacji wartości, gdyż proces ten dokonuje się w kontekście interakcji. Według Marii Gołaszewskiej, fenomen internalizacji pojedynczych wartości obejmuje następujące etapy: po pierwsze, informację (dowiadywanie się o istnieniu wartości); po drugie, transformację (przetłumaczenie informacji na własny, indywidualny język odbiorcy i odniesienie jej do własnych doświadczeń); po trzecie, zaangażowanie (dokonanie wyboru: akceptację danej wartości bądź jej odrzucenie); po czwarte, inkluzję (włączenie wartości w osobiście uznawany system aksjologiczny, co może niekiedy powodować konieczność modyfikacji jego dotychczasowych elementów); po piąte, dynamizację (podjęcie określonych działań bądź przynajmniej przyjęcie określonych postaw w stosunku do rzeczywistości) ${ }^{21}$.

\section{Korelacje wartości i interesów}

Jednym z przejawów aplikacji perspektywy relacjonistycznej w odniesieniu do kategorii aksjologicznych są korelacje zachodzące między wartościami i interesami, np. w kontekście ich funkcji, różnic, analogii. Niewątpliwie te dwie kategorie do pewnego stopnia determinują orientacje życiowe jednostek i są motywatorami i regulatorami relacji społecznych, określają zachowania, formy aktywności podmiotów. W obrębie pierwszej z nich - aksjonormatywnej orientacji - funkcjonują różne hierarchie czy systemy wartości, norm, które pozwalają podmiotom oceniać swoje zachowania i działania z perspektywy moralności (np. jako dobre czy złe). W sytuacji naruszenia czy nierespektowania deklarowanych, a tym bardziej uznawanych preferencji czy celów życiowych mogą pojawić różne doświadczenia: np. poczucie osobistej winy, sankcje społeczne, elementy dezintegracji życia publicznego. Z kolei interesy (indywidualne, grupowe) - jako tzw. pragmatyczna orientacja - obejmują utylitarne (instrumentalne, hedonistyczne) nastawienia do deklarowanych wartości czy urzeczywistnianych czynności. Ten pragmatyczny system odniesień dotyczy utylitarnej kalkulacji, na podstawie której człowiek dokonuje taksonomii swoich zachowań i działań z punktu widzenia własnego interesu (korzyści, niekorzyści czy ewentualnie strat) ${ }^{22}$.

${ }^{20}$ F. Adler, The Value Concept in Sociology, „The American Journal of Sociology” 1956, nr 3, s. $272 \mathrm{nn}$.

${ }^{21}$ M. Gołaszewska, Internalizacja wartości..., s. 91.

${ }^{22}$ E. Wnuk-Lipiński, Socjologia życia publicznego, Wydawnictwo Naukowe Scholar, Warszawa 2005, s. $178-183$. 
Niewątpliwie tym, co łączy wartości i interesy jest analogiczny modus ich funkcjonowania, "przejmowania” od innych w procesie socjalizacji, edukacji, naśladownictwa, ale także artykułowania, a zwłaszcza oddziaływania na zachowania i działania podmiotów. Oba te pojęcia dotyczą przekonań jednostek, łączą się ze sferą subiektywnych celów ludzkiej aktywności, ale są również elementami świadomości społecznej. Dlatego wspólne wartości i interesy przyczyniają się do zawiązywania relacji społecznych i powstawania różnych społeczności oraz określania struktury teleologicznej w doświadczeniu jednostek. Jeśli chodzi o ostatnią kwestię to wartość jest celem uznawanym za słuszny, właściwy czy też usprawiedliwiony; wskazuje na działania podjęte bez motywu uzyskania konkretnych lukratywności (intratności, gratyfikacji), bo dominują tu tzw. inklinacje godziwe. Przykładem takiego podejścia jest stanowisko Stefana Nowaka, który stwierdza, że wartości to „pewne obrazy czy wizje rzeczy, stanów czy procesów pożądanych, uznanych za właściwe, słuszne, czy też takie, jakich by się chciało”23.

Natomiast interes jest celem odnoszącym się do kwestii o charakterze nierzadko partykularnym i egocentrycznym, definiowanym jako coś korzystnego, utylitarnego; stanowiącym działanie nakierowane na uzyskanie konkretnej i wymiernej korzyści przez jednostkę czy grupę ${ }^{24}$. Realizując interesy, jednostka dąży zwykle do korzyści osobistych albo małej grupy (np. własnej rodziny) czy większej zbiorowości (choćby partii politycznej), której jest członkiem. $\mathrm{Z}$ perspektywy interesów można bez większej trudności zdefiniować wszelkie podziały, przeciwstawne dążenia, czyli odnoszące się do tego, co jest „moje” i „twoje”, „nasze” i „obce”. Dlatego interesy bardziej niż wartości determinują konflikty, polaryzacje. Natomiast wartości mają zwykle ponadgrupowy charakter; są nastawione na określone bonum commune i intensywniej „Zapraszają” do kooperacji. Odnoszą się nie tylko do celów danych struktur, w których jednostka partycypuje, ale urzeczywistniając (internalizując) wartości, można dążyć także do dobra społeczności, do których się nie należy, bądź nawet do uniwersalnego dobra wspólnego (wszystkich ludzi) ${ }^{25}$.

A zatem wartości łączą się z interesami, ale się do nich nie redukują. Nie sposób stawiać znaku równości między nimi. W sensie teoretycznym obie te orientacje, aksjonormatywną i pragmatyczną, umieszczamy na różnych poziomach (stopniach) w strukturze modelu motywatorów i regulatorów relacji społecznych,

${ }^{23}$ S. Nowak, Postawy, wartości i aspiracje społeczeństwa polskiego. Przesłanki do prognozy na tle przemian dotychczasowych, w: Społeczeństwo polskie czasu kryzysu. Przeobrażenia świadomości $i$ warianty zachowań, red. S. Nowak, Instytut Socjologii Uniwersytetu Warszawskiego, Warszawa 1984, s. 203.

${ }^{24}$ M. Ziółkowski, Przemiany interesów i wartości społeczeństwa polskiego..., s. 57; P. Pluciński, Kolonizacja świata życia a nowe ruchy społeczne. Postmaterializm po polsku, w: Własność i interesy $w$ dobie transformacji ustrojowej, red. J. Tittenbrun, Wydawnictwo Rys, Poznań 2006, s. 219-220.

${ }_{25}$ M. Ziółkowski, Przemiany interesów i wartości społeczeństwa polskiego..., s. 57-59. 
preferencji i orientacji podmiotów. Ale w praktyce trudno jest nieraz wytyczyć precyzyjne granice między nimi, bo każdy z nas w taki czy inny sposób łączy w swoim życiu obie te orientacje, doświadcza wpływu obu tych regulacji czy motywacji na swoje czynności. Z tej racji jeden obiekt może być jednocześnie i wartością, i interesem, choć ten ostatni - w sensie obiektywnej oceny - nie zawsze jest wartością, a z kolei wartość nie musi być interesem, bo jednostki realizują również takie cele, które uważają za słuszne, lecz jednocześnie są one dla nich niekorzystne ${ }^{26}$.

Z omawianymi kategoriami związane są również różne konflikty czy dysharmonie. Dochodzi do nich zarówno w sferze samych wartości czy interesów, jak i między jednymi i drugimi „regulatorami”. Przy czym z reguły - jak się wydaje - to interes znacznie częściej, niż wartość, łączony jest ze zjawiskiem konfliktu czy "grą o sumie zerowej”. Jeśli chodzi o pierwszy aspekt napięcia, to dochodzi do niego w sytuacji, gdy jednostki poświęcają jedną wartość, aby zachować czy uratować inną (np. oddanie własnego życia w obronie ojczyzny czy wiary). Inna przyczyna sprzeczności między kategoriami aksjologicznymi związana jest z tzw. „segmentyzacją wartości”. Pojęcie to oznacza, że zachowania i działania osób w różnych segmentach ich aktywności czy w określonych kręgach i środowiskach społecznych (np. w sferze życia prywatnego i publicznego; w sytuacjach codziennych, zwyczajnych i uroczystych, nadzwyczajnych) - moga być regulowane czy determinowane przez odmienne wartości. Może również zdarzyć się, że pewien rodzaj wartości, który wcześniej pełnił funkcję dominującego regulatora w życiu jednostki, obecnie współkonkuruje, na tzw. rynku idei, $\mathrm{z}$ innymi elementami aksjologicznymi czy nawet interesami (np. konfrontacja wartości religijnych z celami hedonistycznymi, utylitarnymi).

Ponadto relacje między wartościami mogą być „zakłócane”, gdy ma miejsce absolutyzacja jakiegoś segmentu wartości (nawet wartości wyższych), gdyż taka sytuacja indukuje, że pozostałe kategorie aksjologiczne nie są na swoim, właściwym dla siebie, miejscu („szczeblu”). Rzeczywiście, mamy inklinację, by uznawać za jedyne i zarazem najwyższe te wartości, na które jesteśmy szczególnie uwrażliwieni. W konsekwencji takiego podejścia pojawia się u jednostek zachwiana wrażliwość aksjologiczna, która oznacza, że afirmujemy tylko pewnego typu wartości, a nie dostrzegamy innych lub pomniejszamy ich obiektywną rangę. Takie stanowisko nazywamy „totalizmem aksjologicznym”. Jest to pewnego rodzaju patologia, która może przybierać różne formy: np. hedonizmu, witalizmu, intelektualizmu, moralizmu, estetyzmu itp. ${ }^{27}$. Oczywiście, żaden człowiek nie

${ }^{26}$ E. Wnuk-Lipiński, Kształtowanie się nowego ładu instytucjonalnego, w: Społeczne konsekwencje transformacji ustrojowej, red. M. Grabowska, K. Pankowski, E. Wnuk-Lipiński, ISP PAN, Warszawa1994, s. $15 \mathrm{nn}$.

27 J. Galarowicz, Powołani do odpowiedzialności. Elementarz etyczny, Oficyna Literacka i Naukowa T.I.C., Kraków 1993, s. 39-40. 
jest wolny od dysharmonii, jakie pojawiają się między wartościami, a szczególnie segmentacyjnie zróżnicowanymi. Jednak dla zmniejszenia tego napięcia lub też adekwatnego zarządzania konfliktem wartości istotna jest w takiej sytuacji ich indywidualna hierarchia, tzn. klarowne zdefiniowanie przez jednostkę, które z nich uznaje ona za naczelne, preferowane, a jakie umieszcza na niższych szczeblach „drabiny” aksjologicznej.

Natomiast druga płaszczyzna dysonansu, która dotyczy rozbieżności między wartościami i interesami, polega m.in. na tym, że robimy nierzadko to, czego nie lubimy, rezygnujemy w imię wyznawanej aksjologii z tego, co chcielibyśmy zrobić. Wartościom podporządkowujemy swoje interesy indywidualne (potrzeby, korzyści ${ }^{28}$. Z odwrotną sytuacją mamy do czynienia w życiu społecznym, a zwłaszcza w sferze politycznej, gdy np. partie obiecują w kampanii wyborczej realizację pewnych wartości, ale po dojściu do władzy zapominają o nich, bo w grę wchodzą określone interesy, które wynikają z urzeczywistniania aktualnej strategii władzy, różnych ustępstw czy zawieranych kompromisów (np. między koalicjantami). Z tej racji niektórzy badacze sugerują, że właśnie interesy, a także potrzeby czy przymusy egzystencjalne, odgrywają bardziej pierwszoplanową rolę w eksplikacji preferencji i orientacji podmiotów czy struktury relacji społecznych niż same wartości. Rzeczywiście zdarza się, że w praktyce codziennej wartości „przegrywają” z interesami, tzn. ujawniają swoją „słabość” jako regulatory urządzania życia indywidualnego i społecznego. Taka sytuacja jest rezultatem tego, że kategorie aksjologiczne niejako więcej „wymagają” od podmiotów, jeśli chodzi o ich realizację czy internalizację. I nie każdy potrafi czy ma na tyle w sobie wewnętrznych sił, by podjąć tego rodzaju zaangażowanie czy wyrzeczenie oraz konstruowanie i urzeczywistnianie adekwatnej hierarchii wartości. Poza tym wartości są rozmaicie interpretowane, oceniane, a niekiedy tylko deklarowane, a faktycznie nierealizowane lub mniej czy bardziej kwestionowane w imię doraźnych interesów.

Ponadto do napięcia między wartościami i interesami dochodzi z tego tytułu, że kategorie aksjologiczne nie mogą być - zdaniem niektórych - ustalane metodą referendalną, a inni wyrażają odmienny pogląd. Według pierwszego stanowiska, nie większość społeczeństwa decyduje o tym, czy coś jest wartością, czy nią nie jest oraz nie może czynić z tymi kategoriami aksjologicznymi co jej się podoba. Większość społeczeństwa decyduje o interesach, ale nie o wartościach, np. dobru czy prawdzie ${ }^{29}$. Ale oczywiście nie wszyscy akceptują takie rozwiązanie i dlatego dochodzi z tej racji do konfliktów społecznych.

\footnotetext{
${ }_{28}$ M. Marody, Pojęcie wartości w wyjaśnianiu zachowań społecznych, w: Podstawy życia społecznego w Polsce, red. M. Marody, E. Gucwa-Leśny, ISS UW, Warszawa 1996, s. 166.

${ }_{29}$ J. Mariański, Godność ludzka w kontekście społecznym. Szkice ze społecznego nauczania Kościoła katolickiego, Gaudium, Lublin 2017, s. 280.
} 
Poza tym wartości i interesy bywają w pewnych sytuacjach analogicznie urzeczywistniane, modyfikowane czy rekonstruowane, a w innych okolicznościach zachodzą między nimi w tym względzie istotne różnice. I tak w warunkach stabilizacji, pokoju interesy i wartości zmieniają się powoli i są w zasadzie rekonstruowane. Natomiast w czasach związanych z doświadczeniami wojny, rewolucji czy transformacji systemowej, analizowane kategorie ulegają widocznej fluktuacji czy wręcz mamy do czynienia z kreowaniem nowego systemu aksjologicznego czy pragmatycznego. Wówczas szczególne znaczenie posiadają tzw. „interesy transgresyjne”, które „wynikają z przekroczenia starego systemu, z wyobrażenia sobie jeszcze nie istniejącego stanu przyszłego i swojej potencjalnej pozycji i źródeł korzyści i strat w nowej, dopiero tworzącej się sytuacji”30.

Niewątpliwie oba te regulatory (aksjonormatywny i pragmatyczny) są obecne w życiu jednostek i społeczności. Kategorie aksjologiczne (np. witalne, etyczne, duchowe, religijne) pełnią - mówiąc metaforycznie - funkcję szczebli w strukturze „drabiny” wartości, dzięki którym możliwe jest tworzenie spójnego ładu moralnego. Jednak dla procesu konstruowania i internalizacji adekwatnej hierarchii (systemu) wartości, jak i właściwych relacji między kategoriami aksjologicznymi i pragmatycznymi - istotny jest następujący warunek: to, co jest podstawowe ma służyć temu, co najwyższe oraz to, co jest środkiem nie może zajmować miejsca przeznaczonego dla celu. W przypadku ostatniej kwestii ważne jest, aby instrumentaria były odpowiednio dopasowane do teleologii. Jeśli tak się stanie, to wówczas dane działania można określić mianem działań racjonalnych. Przy czym jeden i drugi system (fundamentalność - najwyższość oraz środki cele) ma swój sens, bo każdy z nich ma do spełnienia określone funkcje, ale one muszą być realizowane na właściwym dla danego układu poziomie. Natomiast nie do przyjęcia jest zamiana ról między tymi układami. Te dwa systemy można porównać do konstrukcji budynku, gdzie położone fundamenty tylko wtedy spełnią swoją funkcję, gdy będą znajdować się na adekwatnym dla siebie miejscu i nie będą próbować zajmować stanowiska przeznaczonego dla ścian domu i vice versa. A zatem nie należy mylić tego, co podstawowe, z tym, co najwyższe ${ }^{31}$.

\section{Wartości a relacje sąsiedzkie Polaków}

Egzemplifikacją aplikacji relacjonistycznej perspektywy w sferze aksjologii są również oglądy typów więzi społecznej, np. relacji sąsiedzkich ${ }^{32}$,

${ }^{30}$ M. Ziółkowski, Przemiany interesów i wartości społeczeństwa polskiego..., s. 82.

${ }^{31}$ Stąd np. życie człowieka jest wartością podstawową, ale nie najwyższą. Dzięki temu możliwe jest poświęcenie czy oddanie swojego życia na rzecz wyższych i najwyższych wartości.

${ }^{32} \mathrm{O}$ więziach sąsiedzkich pisze m.in. Stanisław Ossowski, Urbanistyka i socjologia, w: tenże, Dzieła, t. 3: Z zagadnień psychologii społecznej, PWN, Warszawa 1967, s. 346. 
w kontekście wartości. Więzi sąsiedzkie zachodzą między jednostkami czy wspólnotami (rodzinami) a mniej czy bardziej złożonymi strukturami społecznymi i oznaczają łączność społeczną wytworzoną na podstawie bliskiego zamieszkiwania ludzi na określonej przestrzeni. Skutkiem relacji sąsiedzkich jest istnienie na danym obszarze różnych styczności międzyludzkich, sieci powiązań, form komunikacji interpersonalnej, współdziałania, świadczenia sobie wzajemnej pomocy itp. Jaka jest rola wartości w tego rodzaju sieciach współzależności? Otóż z różnych badań i obserwacji ludzkich doświadczeń wynika, że względnie trwała więź sąsiedzka nie powstaje automatycznie tylko dlatego, że osoby mieszkają blisko siebie, ale muszą zaistnieć istotne czynniki spajające ludzi. Można do nich zaliczyć m.in.: afirmowanie przez podmioty określonych wartości i interesów, autentyczne zaangażowanie się na rzecz realizacji wspólnych celów, wzajemne zaufanie, lojalność, inkluzyjność, sympatię, podobieństwo kultywowanych stylów życia czy normę uogólnionego odwzajemniania (polega na przekonaniu, że wyświadczone przysługi innym będą wynagrodzone w przyszłości).

Dla zilustrowania powyższych refleksji odwołajmy się do danych empirycznych. Otóż z badań CBOS wynika, że dorosły Polak ma średnio trzy osoby, z którymi może porozmawiać o wszystkich swoich problemach, przy czym nieco ponad jedna piąta (22\%) może mówić wyłącznie o jednej takiej osobie $^{33}$. Wprawdzie od 2012 roku nieco zwiększył się odsetek badanych, którzy nie czują się opuszczeni czy osamotnieni w trudnych sytuacjach i mają świadomość, że zawsze mogą liczyć na czyjąś pomoc, to zarazem jednak zmalała przeciętna liczba osób, które - zdaniem respondentów - na pewno nie odmówią im pomocy, rady czy nawet pożyczki, gdy zajdzie taka potrzeba $^{34}$. Poczucie osamotnienia w trudnych sytuacjach życiowych stosunkowo najczęściej towarzyszy badanym niezadowolonym ze swojej sytuacji życiowej (28\% wskazań), mającym od 55 do 64 lat (18\%), z wykształceniem podstawowym (17\%). Jednocześnie należy zauważyć, że od 2005 roku aż o 24 punkty procentowe (z 34\% do 58\%) wzrósł odsetek osób, które twierdzą, że nigdy im się nie zdarzyło odczuwać osamotnienia ${ }^{35}$.

Kreowaniu relacji sąsiedzkich sprzyjają również analogiczne statusy społeczne ludzi, którzy mieszkają obok siebie oraz pewne wzajemne zależności, jakie powstają w wyniku wykonywania określonego zadania czy rozwiązywania zaistniałego problemu. Dlatego np. różne kataklizmy czy niespodziewane zdarzenia wytwarzają nierzadko intensywne, choć zwykle krótkotrwałe, relacje sąsiedzkie. Nieraz ludzi w tego rodzaju stycznościach potrafi „zjedno-

\footnotetext{
33 Więzi społeczne. Komunikat z badań, CBOS, nr 151/2017, Warszawa, listopad 2017, s. 6.

34 Tamże, s. 9.

35 Tamże, s. 10.
} 
czyć” wspólny przeciwnik, np. nieuczciwy developer, „czyściciel” kamienic w ramach afery reprywatyzacyjnej, „truciciel” środowiska naturalnego itp. Kooperacja sąsiedzka, jaka wytwarza się w wyniku konfrontacji podmiotów z nieprzyjaznym i nieprzejrzystym kontekstem, np. instytucjonalnym, stanowi nierzadko rodzaj obrony przed negatywnymi skutkami różnych zjawisk. Poza tym relacje sąsiedzkie (wspólnotowe) mogą istnieć, jak wynika $\mathrm{z}$ różnych badań, w dzielnicach miast uznawanych często za problemowe. Zdarza się bowiem, że chcąc przetrwać i poradzić sobie z różnymi wyzwaniami i trudnymi warunkami egzystencji, jednostki czy rodziny nawiązują ścisłe, w miarę długotrwałe relacje i sieci powiązań, „praktykują” wspomniane reguły świadczenia sobie wzajemnej pomocy.

Z drugiej jednak strony, socjologowie dostrzegają, iż obecnie osłabieniu ulega przestrzenny aspekt sąsiedztwa; relacje między ludźmi mieszkującymi obok siebie stają luźniejsze niż kiedyś. Oznacza to, że fizyczna bliskość osób sama w sobie nie kreuje intensywnych i zażyłych interakcji społecznych. Zwłaszcza w dużych miastach czy tym bardziej w metropoliach ludzie niejako ocierają się o siebie (np. na klatkach schodowych), ale żyją w pewnym dystansie społecznym (nie pozdrawiają się, nie znają sąsiadów z imienia i nazwiska, brak jest wzajemnych wizyt czy świadczenia sobie pomocy). Wpływ na rozluźnienie więzi sąsiedzkich ma, obecny we współczesnej kulturze, fenomen indywidualizmu czy autoseparacji ${ }^{36}$, ale także dążenie do zachowania osobistego czy rodzinnego bezpieczeństwa. Jeśli chodzi o tę ostatnią kwestię, to ludzie unikają kontaktów z innymi ze względu na pewne dramatyczne doświadczenia, jak np. włamania do mieszkań, kradzieże czy niepożądane kontakty choćby z tzw. naciągaczami, domokrążcami. Zachowanie anonimowości, dystansu społecznego jest w takiej sytuacji rodzajem obrony przed różnymi zagrożeniami.

Tendencje te znajdują swoje odzwierciedlenie w rezultatach badań CBOS, z których wynika, że przekonanie o konieczności zachowania ostrożności w relacjach $z$ innymi ludźmi, będące życiową zasadą, jest podzielane nieco częściej niż aplikowane faktycznie w społecznej praktyce działania podmiotów. W kontekście nastawienia do nieznajomych spotykanych w różnych życiowych sytuacjach, 29\% respondentów stwierdziło, iż odnosi się do nich z ufnością. Jednak są to ankietowani, którzy prawie wszyscy zadeklarowali jedynie ograniczone zaufanie (28\% odpowiedzi „raczej mam zaufanie”). Natomiast większość badanych (59\%) wyraziła pogląd, że nie ufa nieznajomym, w tym co dziesiąty traktuje osoby spotkane po raz pierwszy bardzo nieufnie i podejrzliwie ${ }^{37}$. Wyniki te pokazują duży dystans i nieufne nastawienie

${ }^{36}$ U. Beck, Społeczeństwo ryzyka. W drodze do innej nowoczesności, Wyd. Naukowe Scholar, Warszawa 2002, s. 203.

37 O nieufności i zaufaniu. Komunikat z badań, CBOS, nr 35/2018, Warszawa, marzec 2018, s. 2. 
wobec nieznajomych, nieodnotowane dotąd w badaniach CBOS. Oznacza to, że aktualny poziom nieufności (dane z 2018 r.) wobec nieznanych osób jest najwyższy od 2006 roku $^{38}$. W sumie badanym (68\%) można przypisać nieufne, ostrożne podejście do innych, przy czym jedna czwarta ankietowanych zadeklarowała stanowisko zdecydowanej nieufności. Respondenci ci we wszystkich kwestiach identyfikowali się z opcją nakazującą ostrożność i wskazującą na ograniczone zaufanie do nieznanych osób. W opozycji do nich znalazło się 25\% badanych, których cechuje w miarę: życzliwość, zaufanie, otwartość wobec innych ludzi. Te ostatnie wartości, ale w stopniu dużym można przypisać co jedenastemu respondentowi (9\%). Zasadniczo jednak w społeczeństwie polskim nieufność i ostrożność w nastawieniu do bliźnich generalnie biorą górę nad ufnością i otwartością ${ }^{39}$. Różne mogą być tego przyczyny, ale większość z nich łączy się, jak się wydaje, ze wspomnianym dążeniem do zachowania osobistego czy rodzinnego bezpieczeństwa, a także z coraz bardziej obecną w świadomości Polaków orientacją indywidualistyczną.

Ponadto na transformację więzi sąsiedzkich oddziałują również nierówności społeczne (np. wynikające ze zróżnicowań w zakresie statusu majątkowego), które implikują zjawisko dystansu społecznego między ludźmi. Natomiast pewna egalitarność czy podobne położenie materialne jednostek czy rodzin sprawiają, że sąsiedzi chętniej otwierają dla siebie nawzajem podwoje do swoich mieszkań czy domów. Takie zachowania opierają się na przekonaniu, że skoro wyposażenie gospodarstw domowych w przedmioty trwałego użytkowania jest analogiczne u niemal wszystkich, to nie ma sensu stwarzać jakichś barier dla kontaktów sąsiedzkich czy ukrywać przed innymi swojego stanu posiadania, wystroju mieszkań, domów. Jednostki w takiej sytuacji raczej bez skrępowania utrzymują ze sobą w miarę intensywne i zażyłe interakcje ${ }^{40}$.

Oczywiście, ten przestrzenny (lokalny) wymiar relacji sąsiedzkich nie dla wszystkich ulega dewaloryzacji. Istotny jest choćby dla osób starszych. Nierzadko ze względu na stan zdrowia czy zasoby finansowe ich ruchliwość społeczna, poza lokalne środowisko, jest ograniczona. Ponadto nie wszyscy mogą, $\mathrm{z}$ różnych względów, partycypować w dobrodziejstwach suburbanizacji $^{41}$. Dlatego pojawiają się w miastach oddolne inicjatywy, które mają na

38 Tamże, s. 3.

39 Tamże, s. 4.

40 Do okoliczności sprzyjających w nawiązywaniu i podtrzymywaniu sąsiedzkich relacji można zaliczyć tzw. małą architekturę, jak np. ławeczki przed wiejskim gospodarstwami, które niestety w wielu miejscowościach są obecnie rzadkością.

${ }^{41}$ Suburbanizacja zasadniczo oznacza pracę w mieście i zamieszkanie na wsi czy na terenach podmiejskich. Odbywa się w ten sposób „ucieczka” jednostek od miejskiego społeczeństwa masowego, w którym bytowanie ludzi jest w dużym stopniu anonimowe. Zamieszkanie poza wielkim miastem, wśród znanych sobie ludzi, w stałym kontakcie z przyrodą, jest przez wielu traktowane jako ratunek 
celu reaktywowanie więzi sąsiedzkich oraz integrację mieszkańców danego osiedla czy dzielnicy. Podejmowane są przedsięwzięcia ukierunkowane na poprawę jakości życia mieszkańców. Można więc powiedzieć, że fenomen sąsiedztwa nie zanika, ale przybiera nowe formy. $Z$ tej racji tradycyjne relacje sąsiedzkie, mające postać społecznego zorganizowania na określonej przestrzeni, przeplatają się z tzw. nową koncepcją sąsiedztwa, które w coraz większym stopniu ufundowane jest na społecznej bliskości. Oznacza to, że ludzie najpierw łączą się ze sobą po to, aby wspólnie realizować określone przedsięwzięcia, a następnie dopiero pojawiają się geograficzne dookreślenia dla tego typu podejmowanych aktywności ${ }^{42}$.

Jaka w tym wszystkim jest rola wartości i interesów? Otóż ta nowa wizja sąsiedztwa opiera się na uznawanych i realizowanych kategoriach aksjonormatywnych i pragmatycznych jako motywatorach i regulatorach omawianych relacji, na zdolności do działań na rzecz dobra wspólnego, zaufaniu i lojalności, długotrwałej kooperacji, istnieniu społeczno-kulturowego milieu i infrastruktury instytucjonalnej. Innymi słowy, istotnymi determinantami nowego sąsiedztwa są czynniki psychospołeczne, które sprawiają, że podmioty skłonne są sobie ufać i współpracować ze sobą zarówno w miejscu zamieszkania, jak również wtedy, gdy nawiązują interakcje na gruncie wspólnej aksjologii (wartości) czy pragmatyki (interesów) oraz akceptacji adekwatnego wyposażenia instytucjonalnego (np. istnienia lokalnych ruchów społecznych czy organizacji sąsiedzkich, obywatelskich, procedur partycypacyjnych czy reguł formalno-prawnych).

Sąsiedztwo, poza jego tradycyjną i nową postacią, jest zróżnicowane ze względu na stopień zaangażowania mieszkańców we wzajemne relacje. Uwzględniając tego rodzaju perspektywę, niektórzy wyodrębniają następujące rodzaje sąsiedztwa: ograniczające, poinformowane, konwencjonalne, świadczeniowe, solidarnościowe, towarzysko-przyjacielskie ${ }^{43}$. Pierwsze z nich oparte jest na określonej strukturze oczekiwań i powinności w stosunku do współmieszkańców. Podstawowym jego elementem jest świadomość ograniczeń wynikających z bliskości sąsiadów. Z kolei sąsiedztwo poinformowane odnosi się do mimowolnego albo świadomego gromadzenia informacji o współmieszkańcach. Następna kategoria polega na wymianie konwencjonalnych ukłonów i pozdrowień. Natomiast sąsiedztwo świadczeniowe jest typem relacji

\footnotetext{
przed utratą tożsamości indywidualnej i społecznej, przed „wykorzenieniem”. Lokalność staje się w ten sposób remedium na „samotność w tłumie”.

42 Sąsiedztwa i mikroorganizacje $w$ polskiej przestrzeni społecznej - próba diagnozy i rekomendacje. Badanie mikroorganizacji - grup sąsiedzkich, red. W. Łukowski, Ministerstwo Pracy i Polityki Społecznej, Departament Pożytku Publicznego, Warszawa 2009, s. 24.

${ }_{43}$ P. Kryczka, Społeczność osiedla mieszkaniowego $w$ wielkim mieście. Ideologie i rzeczywistość, PWN, Warszawa 1981, s. 113-157.
} 
zbliżonych do tradycyjnych społeczności lokalnych - charakteryzuje się bezpośrednimi i intensywnymi interakcjami członków danej wspólnoty (ludzie częściej świadczą sobie drobne przysługi oraz bywają u siebie, odwiedzają się nawzajem). Dla sąsiedztwa solidarnościowego osią integracji jest poczucie jedności i wspólności interesów ze względu na analogiczną sytuację wynikającą z bliskiego zamieszkiwania. Ostatni rodzaj sąsiedztwa (towarzysko-przyjacielskiego) jest formą interakcji o najwyższym stopniu zaangażowania osobistego.

W kontekście przytoczonej taksonomii sąsiedztwa, warto przywołać wyniki badań socjologicznych. Dla przykładu postawy solidarystyczne ${ }^{44}$ deklarują m.in. polscy studenci: 53\% spośród nich dostrzega konieczność bycia wrażliwym i gotowym do niesienia pomocy innym ludziom. Natomiast $26 \%$ akceptuje stanowisko „egoizmu społecznego” (tzn. „obecnie trzeba bardziej koncentrować się na walce o swoje sprawy, nie zważając na innych") ${ }^{45}$. A zatem, na poziomie deklaracji, postawy solidarystyczne wyraźnie dominują nad egoistycznymi. Jednak $21 \%$ studentów wybrało odpowiedź „trudno powiedzieć" $"$ ". A poza tym warto zauważyć, że deklaracje gotowości do okazywania wsparcia innym nie zawsze korespondują $\mathrm{z}$ faktycznymi aktami pomocy.

Z kolei z eksploracji CBOS wynika, że Polacy w zdecydowanej większości (89\%) nie unikają sąsiadów i kontaktów z nimi, ale jednocześnie większość $\mathrm{z}$ nich (65\%) przyznaje, że utrzymuje dystans w tego rodzaju relacjach. Takie rezultaty badań oznaczają chęć utrzymywania w miarę poprawnych, ale jednocześnie niezbyt bliskich kontaktów ze współmieszkańcami określonego terytorium ${ }^{47}$. W praktyce relacje te redukują się do tzw. kontaktów grzecznościowych (wymiana pozdrowień, witanie się z napotkanymi sąsiadami). 84\% badanych utrzymuje tego rodzaju kontakty przynajmniej z niektórymi sąsiadami, w tym $27 \%$ przyznaje, że ten typ relacji charakteryzuje jego kontakty z większością sąsiadów. Jeśli chodzi o świadczenie sobie drobnych przysług, jak np. pożyczenie czegoś, popilnowanie dziecka, to $72 \%$ badanych zadeklarowało aplikowanie tego rodzaju praktyk. Jednak zdecydowana większość badanych (64\%) przyznała, że tak zażyłe stosunki łączą ich tylko z nielicznymi sąsiadami. 35\% ankietowanych twierdzi, że utrzymuje z sąsiadami kontakty towarzyskie (wzajemne odwiedziny, bywanie u siebie na imieninach i innych uroczystościach rodzinnych). Ale $z$ reguły nie są to zbyt liczne relacje (32\% badanych twierdzi, że ma od jednego do pięciu takich sąsiadów).

Jeśli chodzi o wspomniane m.in. relacje sąsiedzkie o charakterze konwencjonalnym, świadczeniowym i towarzyskim, to utrzymują się one, jak

${ }^{44}$ Postawy te w tych badaniach odnoszą się nie tylko do sąsiadów.

${ }_{45}$ A. Guzik, R. Marzęcki, Ł. Stach, Pokolenie '89. Aksjologia i aktywność młodych Polaków, Wyd. Naukowe UP, Kraków 2015, s. 125.

${ }^{46}$ Tamże.

${ }^{47}$ Relacje sąiedzkie. Komunikat z badań, CBOS, nr 146/2017, Warszawa, listopad 2017, s. 1. 
wynika z badań CBOS, od co najmniej kilku lat na zbliżonym poziomie. Jednak zawęża się grono sąsiadów, z którymi Polacy utrzymują relacje konwencjonalne oraz świadczeniowe (coraz rzadziej dotyczą one większości sąsiadów, częściej zaś tylko nielicznych) ${ }^{48}$. Przy czym więzi sąsiedzkie zależą w pewnej mierze od typu i wielkości społeczności lokalnej. I tak, na obszarach wiejskich zdecydowanie rzadziej, niż w miastach kontakty sąsiedzkie mają charakter wyłącznie konwencjonalny, częściej zaś świadczeniowy i towarzyski. Z drugiej zaś strony, bardziej intensywne i bezpośrednie relacje sąsiedzkie na wsi częściej sprzyjają pojawianiu się konfliktów między ludźmi. Z kolei świadczeniowe relacje sąsiedzkie częściej dotyczą mieszkańców małych miast ${ }^{49}$. Bliskie relacje sąsiedzkie wykazują przede wszystkim osoby w wieku od 45 do 54 lat (44\%), badani praktykujący religijnie kilka razy w tygodniu (44\%), osoby o relatywnie niskich dochodach per capita (42\%) oraz mieszkające na wsi (40\%). Zestawienie wskaźnika dobrego sąsiedztwa (chodzi o utrzymywanie zarówno kontaktów towarzyskich, jak i świadczeniowych przynajmniej z niektórymi sąsiadami) z opiniami na temat zachowywania dystansu wobec sąsiadów - potwierdza powyżej sformułowaną tezę, że brak bliższych relacji ma związek z preferowaniem stosunków poprawnych, lecz nie zażyłych. Spośród badanych, którzy nie utrzymują z sąsiadami kontaktów towarzyskich ani świadczeniowych, 79\% twierdzi, że stara się postępować tak, aby nikt $z$ sąsiadów nie miał do nich pretensji i dlatego zachowuje w stosunku do nich dystans społeczny. Z kolei wśród osób deklarujących bliskie relacje odsetek ten obejmuje $52 \%$ ankietowanych ${ }^{50}$.

W kontekście przytoczonych wyników badań można stwierdzić, że walor więzi społecznych ma wpływ na jakość zaangażowania jednostek w różne formy samoorganizacji czy mobilizacji podczas działań zbiorowych. Autentyczne (niepozorowane) interakcje - podejmowane w imię czy na rzecz określonych wartości, interesów - stanowią w miarę silne źródło gotowości do aktywności na rzecz innych. Dlatego w sytuacji istnienia dystansu społecznego niewątpliwie maleje zakres zaangażowania jednostek na rzecz bliźnich. Przy czym należy zauważyć, że więzi społeczne, w tym i relacje sąsiedzkie, stanowią nie tylko fundament dla partycypacji społecznej, ale i jej rezultat. Mamy tu do czynienia z systemem naczyń połączonych (fenomenem sprzężenia zwrotnego). W każdym razie, im słabsza jest więź między podmiotami czy też między jednostkami a celami ich działalności, tym mniejsze jest prawdopodobieństwo społecznego zaangażowania ludzi i vice versa.

\footnotetext{
48 Tamże, s. 2-3.

49 Tamże, s. 4.

50 Tamże, s. 5.
} 


\section{Uwagi końcowe}

Zasadniczy walor relacjonistycznej perspektywy w odniesieniu do problematyki aksjologicznej polega na tym, że implikuje ona aktywistyczną koncepcję wartości. Dlatego jest ona szczególnie cenna dla socjologa, gdyż umożliwia mu zajmowanie się tym, co jest specyfiką jego dyscypliny: badanie i analizowanie faktycznych, a nie tylko deklarowanych werbalnie, zachowań i działań podmiotów funkcjonujących w sieci różnych interakcji. Z tej racji socjologiczne badania nad wartościami - dokonywane z relacjonistycznego punktu widzenia - dostarczają wielu cennych informacji na temat aktywności podmiotów czy transformacji, rekonstrukcji struktury fenomenów życia publicznego. Oznacza to, że nie sposób zrozumieć specyfiki badanych zjawisk, jeśli nie uwzględni się problematyki wartości. Również aplikacja podejścia badawczego łączącego optykę aksjonormatywną z pragmatyczną umożliwia socjologowi ujmowanie m.in. różnych społecznych więzi, identyfikacji, ale także dystansów, antagonizmów czy preferencji. W wielu przypadkach akceptowany system wartości czy interesów przekłada się - w takiej czy innej postaci - na afirmowany styl życia, określoną tożsamość, solidarność oraz zachowania i działania podmiotów. Oznacza to, że wspólne wartości i interesy, pełniące funkcje motywatorów i regulatorów, są jednym $z$ istotnych czynników kreowania poczucia społecznego „my”, a także intencjonalnego współdziałania. Kategorie aksjologiczne i pragmatyczne przejawiają się m.in. w sposobie mówienia i myślenia o rzeczywistości, określają typy i jakość dyskursu, są modusem definiowania swojej tożsamości indywidualnej i zbiorowej, obroną bądź podwyższaniem samooceny.

Relacjonistyczne (podmiotowo-przedmiotowe) ujmowanie wartości pozwala również opisać ich rolę (funkcje) w procesach integracji społecznej. Kategorie aksjologiczne i normy społeczne (uznawane i realizowane), interakcje podmiotów - są dopiero warunkami wstępnymi integracji. O samej integracji można mówić dopiero wtedy, gdy w systemie społecznym wytworzy się - w kontekście relacjonistycznym - poczucie wspólnotowości. Analizując czy prowadząc badania empiryczne, z punktu widzenia podmiotowo-przedmiotowej perspektywy, a dotyczące warunków wzrostu lub zaniku integracji, należy brać pod uwagę łączne spełnienie wszystkich tych warunków: tzn. obecność w świadomości społecznej wspólnych wartości i norm społecznych, istnienie spajających czynności i interakcji, oraz występowanie identyfikacji z grupą.

\section{Bibliografia}

Adler F., The Value Concept in Sociology, "The American Journal of Sociology" 1956, nr 3, s. $272-279$. Beck U.,Społeczeństwo ryzyka. Wdrodze do innejnowoczesności, Wyd. Naukowe Scholar, Warszawa 2002. 
Donati P., Archer M.S., The Relational Subject, Cambridge University Press, Cambridge 2015.

Donati P., Sociologia della relazione, Società editrice il Mulino, Bologna 2013.

Galarowicz J., Powołani do odpowiedzialności. Elementarz etyczny, Oficyna Literacka i Naukowa T.I.C., Kraków 1993.

Gołaszewska M., Internalizacja wartości, „Etyka” 1978, t. 16, s. 81-102.

Guzik A., Marzęcki R., Stach Ł., Pokolenie' '89. Aksjologia i aktywność młodych Polaków, Wyd. Naukowe UP, Kraków 2015.

Jałowiecki S., Struktura systemu wartości. Studium zróżnicowań międzygeneracyjnych, PWN, Warszawa-Wrocław 1978.

Koralewicz-Zębik J., System wartości a struktura społeczna, Ossolineum, Wrocław 1974.

Kowalczyk S., Człowiek w poszukiwaniu wartości. Elementy aksjologii personalistycznej, Wydawnictwo KUL, Lublin 2006.

Kryczka P., Społeczność osiedla mieszkaniowego w wielkim mieście. Ideologie i rzeczywistość, PWN, Warszawa 1981.

Mariański J., Godność ludzka w kontekście społecznym. Szkice ze społecznego nauczania Kościoła katolickiego, Gaudium, Lublin 2017.

Nowak S., Postawy, wartości i aspiracje społeczeństwa polskiego. Przesłanki do prognozy na tle przemian dotychczasowych, w: Społeczeństwo polskie czasu kryzysu. Przeobrażenia świadomości i warianty zachowań, red. S. Nowak, Instytut Socjologii Uniwersytetu Warszawskiego, Warszawa 1984, s. 182-230.

O nieufności i zaufaniu. Komunikat z badań, CBOS, nr 35/2018, Warszawa, marzec 2018.

Ossowski S., Urbanistyka i socjologia, w: tenże, Dzieła, t. 3: Zzagadnień psychologii społecznej, PWN, Warszawa 1967, s. 337-349.

Paleczny T., Socjologia tożsamości, Oficyna Wydawnicza AFM Kraków 2008.

Pluciński P., Kolonizacja świata życia a nowe ruchy społeczne. Postmaterializm po polsku, w: Własność i interesy w dobie transformacji ustrojowej, red. J. Tittenbrun, Wydawnictwo Rys, Poznań 2006, s. 215-239.

Relacje sq̨siedzkie. Komunikat z badań, CBOS, nr 146/2017, Warszawa, listopad 2017.

Sąsiedztwa i mikroorganizacje w polskiej przestrzeni społecznej - próba diagnozy i rekomendacje. Badanie mikroorganizacji - grup sąsiedzkich, red. W. Łukowski, Ministerstwo Pracy i Polityki Społecznej, Departament Pożytku Publicznego, Warszawa 2009.

Sens życia - wczoraj i dziś. Komunikat z badań, CBOS, nr 41/2017, Warszawa, kwiecień 2017.

Świda H., Młodzież a wartości, WSiP, Warszawa 1979.

Szczepański J., Elementarne pojęcia socjologii, PWN, Warszawa 1970.

Sztompka P., Kapitał społeczny. Teoria przestrzeni międzyludzkiej, Wydawnictwo Znak Kraków 2016.

Thomas W. I., Znaniecki F., Chłop polski w Europie i Ameryce, t. I, LSW, Warszawa 1976.

Więzi rodzinne. Komunikat z badań, CBOS, nr 61/2019, Warszawa, kwiecień 2019.

Więzi społeczne. Komunikat z badań, CBOS, nr 151/2017, Warszawa, listopad 2017.

Wnuk-Lipiński E., Kształtowanie się nowego ładu instytucjonalnego, w: Społeczne konsekwencje transformacji ustrojowej, red M. Grabowska, K. Pankowski, E. Wnuk-Lipiński, ISP PAN, Warszawa 1994, s. 9-23.

Wnuk-Lipiński E., Socjologia życia publicznego, Wydawnictwo Naukowe Scholar Warszawa 2005.

Ziółkowski M., Przemiany interesów i wartości społeczeństwa polskiego. Teorie, tendencje, interpretacje, Wydawnictwo Fundacji Humaniora, Poznań 2000.

Ziółkowski M., Wartości, w: Encyklopedia socjologii, t. 4, Oficyna Naukowa, Warszawa 2002, s. 289-297. Znaniecki F., Nauki o kulturze. Narodziny i rozwój, PWN, Warszawa 1992. 


\title{
Socjologiczne rozumienie wartości w aspekcie relacjonistycznym
}

\section{Streszczenie}

Celem niniejszego tekstu jest zaprezentowanie najpierw, z podmiotowo-przedmiotowej (psychospołecznej) perspektywy, ontologicznego aspektu wartości, a następnie ukazanie jej waloru aplikacyjnego (przedmiotem analizy są korelacje zachodzące między wartościami i interesami, oraz kategoriami aksjologicznymi i więziami sąsiedzkimi Polaków). Walor stosowania perspektywy relacjonistycznej, w odniesieniu do sfery aksjologicznej (wartości) i pragmatycznej (interesy), polega na tym, że umożliwia ona bardziej adekwatne w sensie epistemologicznym oglądy badanych podmiotów czy fenomenów życia społecznego (np. relacji sąsiedzkich). Ujmowanie wartości czy interesów, z psychospołecznego punktu widzenia, pozwala również opisać ich znaczenie w procesach integracji społecznej, pełnienia przez nie funkcji motywatorów i regulatorów ludzkich zachowań i działań, ale i tzw. fenomenu maski czy fasady (wartości są tylko rytualnymi formułami ukrywającymi rzeczywiste przyczyny dokonywanych opcji czy podejmowanych decyzji).

Słowa kluczowe: wartości, relacjonistyczna perspektywa, interesy, relacje sąsiedzkie

\section{The relationist perspective on the sociological understanding of values}

\begin{abstract}
The aim of the text is to present, from the subject-object (psychosocial) perspective, the ontological status of values, and, secondly, to explicate the merits of applying this perspective (the object of the analysis is the correlation between values and interests, and between axiological categories and neighbourly ties of the Poles). The relationist perspective, applied to the axiological (values) and pragmatic (interests) spheres, allows a more accurate (in an epistemological understanding of the term) perception of the analysed subjects or the phenomena of social life (e.g. neighbourly relations). What is more, from the psychosocial perspective, analysing values and interests makes it possible to describe their significance in the processes of social integration, their functioning as motivators and regulators of human behaviour, and their functioning as the so-called mask or façade (values are merely ritualistic forms that obscure true motives behind actions or choices).
\end{abstract}

Key words: values, relationist perspective, interests, neighbourly relations 